JNUS:Journal of Nahdlatul Ulama Studies Vol. 2, No. 1, Januari 2021: p. 1-16. DOI: 10.35672/jnus.v2i1.1-16

Website: http://jnus.lakpesdamsalatiga.or.id/index.php/jnus/index

\title{
Tahlilan Tradition as Media for National Character Education
}

\author{
Alif Nurul Mubarok \\ Master Program of Islamic Education \\ Education and Teacher Training Faculty \\ UIN Sunan Kalijaga Yogyakarta \\ mubarokalie38@gmail.com
}

\begin{abstract}
Tahlilan is one of the ancestral traditions of the Indonesian nation which is rich in social values. Apart from functioning as a religious ritual, it is also meaningful as a medium for character education. Through the field research method, this research seeks to reveal the values of character education contained in the tahlilan tradition, especially tahlilan carried out by the people of Losari Village, Losari District, Cirebon Regency. The results of this study found that there are so many values of character education contained in the tahlilan tradition in Losari Village, namely; diversity, social concern, hard work, and discipline. Thus, it can be said that the tahlilan tradition can function as the basis for character education for the Indonesian nation, especially among the Indonesian Muslim community.
\end{abstract}

Keywords: tradition, tablilan, character education

\begin{abstract}
Abstrak
Tahlilan merupakan salah satu tradisi warisan leluhur bangsa Indonesia yang kaya akan nilai-nilai sosial. Selain berfungsi sebagai ritual keagamaan juga bermakna sebagai media pendidikan karakter. Melalui metode penelitian field reasearch, penelitian ini berupaya megungkap nilai-nilai pendidikan karakter yang terkandung dalam tradisi tahlilan, khususnya tahlilan yang dilaksanakan oleh masyarakat Desa Losari Kecamatan Losari Kabupaten Cirebon. Hasil penelitian ini menemukan bahwa terdapat begitu banyak nilai-nilai pendidikan karakter yang terkandung dalam tradisi tahlilan di Desa Losari di antaranya yaitu; keberagamaan, kepedulian sosial, kerja keras, dan kedisiplinan. Dengan demikian, maka dapat dikatakan bahwa tradisi tahlilan dapat difungsikan sebagai basis
\end{abstract}


JNUS: Journal of Nahdlatul Ulama Studies, Vol. 2, No. 1, Januari 2021: 1-16

pendidikan karakter bagi bangsa indonesia, khususnya di kalangan masyarakat muslim Indonesia.

Kata Kunci: tradisi, tablilan, pendidikan karakter

\section{INTRODUCTION}

The character of the Indonesian nation is currently receiving special attention from the government. This happens when there is a moral decline that occurs in various levels of society. Starting from the general public to even educated people. According to the expert team of Jati Diri Bangsa Foundation's, this condition is caused by a decrease in the ability to accept and appreciate differences of opinion, a lack of concern and a gap between what is seen and what is done (Tim Pakar Yayasan Jati Diri Bangsa, 2011:30-33).

Indications of moral decline are shown in 2016 UNICEF data showing that violence against adolescents in Indonesia is estimated at 50 percent. Meanwhile, according to data from the Ministry of Health of the Republic of Indonesia 2017, there were 3.8 percent of students who stated that they had abused narcotics and dangerous drugs. By paying attention to the moral condition of the Indonesian nation, Indonesia needs a formula to improve the morale of the Indonesian nation through character education (fk.ugm.ac.id, accessed on 5 August 2020)

The term character education was strengthened again when Minister of Education Muhammad Nasir in his speech on National Education Day 2011 emphasized the importance of character education as an effort to build the nation's character (Pendidikan Nasional Kementerian, 2011:8). ${ }^{1}$ Because basically a good character will give birth to a good order, and vice versa. This character education cannot be realized by only one party, but involves all parties in the family, school and community.

Indicators of character education values formulated by the government have a relationship with a tradition in society. According to M. Mahbubi, the aswaja tradition which became NU's amaliyab (deed) has

${ }^{1}$ There are 18 character values in building national character, namely religious, honest, tolerance, discipline, hard work, creative, independent, democratic, curiosity, national spirit, love for the country, respect for achievement, friendly/communicative, peace-loving, fond of reading, environmental care, social care, responsibility. 
been in accordance with the indicators of character education values set by the Ministry of National Education in the 2045 Gold Indonesia Strategic Plan (M. Mahbubi, 2012:149). So in this case the tablilan tradition can be an alternative strategy for shaping the character of the nation.

The beginning of the tablilan tradition in Indonesia emerged as a result of the acculturation of local cultural values with Islamic values. In the old tradition, when someone died, relatives and neighbors gathered at the funeral home. They don't pray for the deceased but stay up late playing gambling, drinking or something.

In this situation, Wali Songo did not immediately dissolve the tradition, but the community was allowed to continue to gather, but the contents were replaced by praying for the deceased and reading tablil, tahmid, prayer beads and sholawat to the Prophet SAW, his family and friends. Therefore, Islam that developed in Indonesia has a variety of cultures that are still preserved such as the tablilan tradition.

Each tradition contains educational values, especially in character education. Education as a process to achieve one's life goals so that someone is considered perfect and has creativity. However, in education it is not only related to creativity, science, and technology, but also about character building and inculcating certain values in a person.

\section{RESEARCH METHOD}

This type of research is descriptive qualitative, namely research that produces descriptive data in the form of written or spoken words from people and observable behavior. The research approach used in this research is a case study approach. Namely an approach that aims to describe and analyze a unique and interesting case to research (Lexy J. Meleong, 2010:6).

Primary data sources are selected by choice and other documents related to research as secondary data sources. Data collection was carried out by interview, observation and documentation. Data analysis is qualitative in nature through three stages: data reduction, data presentation, and verification / conclusion. 
JNUS: Journal of Nahdlatul Ulama Studies, Vol. 2, No. 1, Januari 2021: 1-16

\section{DISCUSSION}

\section{Implementation of Tahlilan Traditions in Losari Village, Losari District, Cirebon District}

The traditional activity of tablilan is a religious custom as a means of taqorrub illallah (getting closer to Allah) either alone or together, gathering to do dhikr (remembering) to Allah by reading kalimah thayibah such as Laa ilaaha illallah, sholawat to the Prophet Muhammad, Qur'anic verses and prayers (Munawir Abdul Fattah, 2007:276). The tablilan tradition is expected to have an influence in increasing values, good habits in society and others in living life.

In human life, there are times when we feel deep within the lowest point of our lives. When the reality faced is different from what we expected. Not infrequently we are already prejudiced against Allah SWT for the tragedies that we experience. This is not justified. Because all the tragedies that befall us are a form of testing from God to forge our faith.

Does this test can draw closer to Allah or vice versa. So one means of getting closer to Allah by dhikr to Allah. Disasters given by Allah are a form of His love for us. So the Indonesian people have a tradition that has been formed from ancient times, namely the tablilan tradition.

The tablilan tradition is also held in Losari Village, Losari District, Cirebon Regency. In this case, the author explains a little about the Tahlilan Tradition according to the data on tahlilan tradition in Losari Village. Losari Village is inhabited by a group of people who are predominantly Muslim who have the Nahdlatul Ulama '(NU) culture.

So, one of the religious activities of the community is the tablilan tradition. Tablilan tradition in Losari village has started long ago and has been passed down from generation to generation. However, no one knows for sure when it was first implemented and who was the first to carry out in Losari village itself. What is clear is that the community believes that the it has existed since ancient times, which has become a habit of the people of Losari village so that it is still often carried out by Losari villagers.

The people of Losari follow what has been done by previous residents or people, from their parents, religious scholars and kiai. This is because the they are part of the rural community, which incidentally most of the level of understanding of their religion is still lacking. So the 
community evaluates and believes that the tablilan tradition is a good habit and is beneficial to society. So that it has been grounded as a means of worship that they carry out.

They carry out tablilan tradition which aims to pray/send prayers (kirim dungo) for the spirits of the grave experts so that the burial expert will receive forgiveness and in his spirit realm he will always receive grace from Allah SWT. In addition, the people of Losari village carry it out the with the aim of getting closer to Allah, as a means of repenting to Allah, and as a means of hoping for the blessing of Allah.

When the community implements tablilan, it must be based on sincere intentions, then we will definitely become grateful experts. The way to become a grateful expert is that when we have a problem, we must introspect ourselves (mubasabah). tablilan means taqorrub illallah (getting closer to Allah) through muhasabah (self-introspection) by admitting that we are weak and awry (Nur Liyana, Ibnu Jazari, dan Ika Anggraheni, 2020:157).

Not only for ourselves, but we also pray for our parents because this is a form of birulwalidain and pray for all Muslims as brothers of the same faith. This objective can be concluded that the tahlilan tradition plays an important role in the life of the people in Losari village.

Tahlilan activities are usually carried out by all levels of society from children, adolescents and to the elderly. And the timing of these activities is carried out whenever and wherever, because the core of the tablil is found in the reading of Laa ilaaha illallah.

While the implementation of tablilan tradition that applies to the Losari village community is usually carried out when a person dies, it is carried out after bathing, before praying until the funeral of the body. Then tablilan tradition is continued on the first day of death until the seventh, fortieth, hundredth day, mendhak pisan (first year), mendhak pindho (second year), mendhak katelu (nyewu), and haul/khol (after reaching one year) which is usually held every one year.

The implementation of the tablilan tradition is not only read when someone dies but tablil is also read at the celebration or tasyakuran event, monthly routine (selapanan), weekly routines, pesantren routines, commemorations of independence and recitation of Islamic holidays such 
JNUS: Journal of Nahdlatul Ulama Studies, Vol. 2, No. 1, Januari 2021: 1-16

as the Prophet's Birthday, Isra 'Mi'raj and other events. It is carried out in every mosque / mosque which is held every Friday night.

The implementation time is often held when the sun has set, namely after maghrib or Isha'. The tablilan tradition is attended by the closest neighbors, is not limited by age and it is led by Kiai or community leaders.

In addition, the people of Losari village carry out the tablilan tradition in every community association or activity in which it is filled with the tablilan Tradition, both from social community gatherings or religious community associations in Losari village, definitely using tablil reading as one of a series of events that included in the activity agenda.

The tablilan tradition is also carried out regularly, religious activities such as congregations of Muslimat NU and Yasinan, which are carried out in the homes of residents who are members which are carried out regularly either once a week or once a month religious activities use or contain the Tahlilan Tradition. be it young or old. In addition, the tablilan tradition is also carried out routinely at the Islamic boarding school in Losari Village, where students are then required to take part in these activities by the head of the boarding school. With the aim of training students so that students can read tablil fluently, train students so that when in the community they can lead tahlilan in their villages. It also makes a characteristic of the Salafiyyah Islamic boarding schools.

\section{Values of Character Education in Tahlilan Tradition}

In the midst of people's udder in the world of education, there is a glimmer of new hope with the arrival of the character education era. On National Education Day 2011, the Minister of Education and Culture of the Republic of Indonesia emphasized the importance of character education as an effort to build the nation's character. Even in the same year the Ministry published a training book and the development of national character culture education compiled by the Research and Development Agency for the Ministry of National Education's Curriculum Center. In a book compiled by the Research and Development Agency for the Ministry of National Education's Curriculum Center, there are 18 values in national character education, namely religion, honesty, tolerance, discipline, hard work, creative, independent, democratic, curiosity, national spirit, love for the country, 
respect achievement, friendly/communicative, peace-loving, fond of reading, environmental care, social care, responsibility. The character of the nation is built on ethical values that come from religious and cultural values. Local wisdom is a value derived from the nation's culture that can make this nation have strong social capital to build national civilization (Muhammad Priyatna, 2017:1312). The tablilan tradition is one of the local wisdoms possessed by the Indonesian people, so in the tahlilan tradition there are several values of character education including:

\section{Religiosity}

Religiosity comes from the word religious which means the nature of religion inherent in a person. Being religious is one of the values of character education as an attitude and behavior that is obedient in carrying out the religious teachings he believes in and has a tolerant spirit towards the implementation of the worship of other religions, and also lives in harmony with followers of other religions (Mohamad Mustari, 2011:1). Religious character education includes one's thoughts, words and actions which are based on divine values (Jamal Ma'mur Asmani, 2011:37).

This religious character is very much needed by the village community, especially children and adolescents in the face of changing times and moral degradation, in this case it is hoped that they will be able to have and behave with good and bad measures based on the provisions and of religion.

In tablilan there is a religious value, namely in the implementation of tardisi tahlilan, it begins when someone dies. Then the villagers took takziyah to the funeral home and participated in burying the corpse. After that a tablilan event was held by shobibul hajat (the corpse's family) and was attended by the village community. When tahlilan is read together by reading the letter Yasin, accompanied by surah al-Fatihah which is devoted to the dead, the verse of the Chair and chanting of tasbih (purification), tahmid (praise) and istighfar (asking for forgiveness).

Then pray for the deceased and his family so that all the sins he has committed while living in the world, will be forgiven by Allah SWT. In addition, the grave was opened and the grave was given by Allah SWT and the reward of the Al-Qur'an recitation and dhikr from relatives and neighbors was given to the deceased. 
JNUS: Journal of Nahdlatul Ulama Studies, Vol. 2, No. 1, Januari 2021: 1-16

Even tablilan is not only performed on the day of death but is continued on the seventh, fortieth, hundredth day, mendhak pisan (first year), mendhak pindho (second year), mendhak katelu, and haul/khol (after reaching one year) which is usually held annually.

In addition to praying for people who have died, the tablilan tradition is also a means of getting closer to Allah, namely by doing dhikr or reading the Al-Qur'an which aims to remember Allah, remember Allah's majesty and hope for Allah's blessing. As servants of Allah, we as humans must always remember the existence of Allah who is worshiped at all times and become grateful servants.

So the tablilan tradition is very influential on the life of the village community, from an activity in which it is filled with the Tahlilan Tradition, it will influence or foster a community character that has high religious social habits, besides that it can also form a Muslim personality, because this activity contains about reading dhikr or verses of the Koran and prayer, this will clearly affect the personality of the Muslim villagers themselves, while the reading of tahlil that is carried out in the village cannot be separated from the Al-Qur'an and recitations of drikir and prayers' a that is recommended by Allah SWT

From this, we already know that the tahlilan tradition shapes a person's religious character. However, it all depends on the person who does it, if the Tahlilan Tradition is done seriously and is intended with good things, there will be a lot of benefits and the formation of religious character in society. And the tahlilan tradition has many benefits, including:

a. Being able to pray for the burial expert;

b. Being able to remember death and remind to always prepare supplies before the arrival of death. The best provision is to always carry out obedient deeds (carry out His obligations and stay away from His prohibitions) and do good deeds (righteous deeds);

c. Being able to feel how a person is when he will face his death (sakaratul maut);

d. Being able to eliminate the joy of the world (so remember the afterlife);

e. Being able to get closer to Allah and expect His good pleasure; 
f. Being able to prevent immoral acts;

g. Being able to relax the heart of someone who has a hard heart;

h. Being able to alleviate calamities (disasters);

i. Being able to reject impurities and strengthen the heart, so that it is not affected by invitations that can lead to sin

\section{Hard Work}

In the language, hard work means never giving up. Hard work is an action that is carried out in earnest without getting tired or stopping before the work target is achieved and always prioritizing or paying attention to the satisfaction of results in every action taken. Hard work can be interpreted as working to have a serious nature to achieve the goals to be achieved.

Hard work is very important for society to do. With hard work, a person can change his own fate for the better. Then society can optimize its potential because humans have been endowed with reason, feeling, and intention so that they must maintain their dignity. Shows an attitude of responsibility by meeting his own needs. In addition, people can live independently so that they do not become a burden to others and participate in advancing the surrounding environment and the country.

In tahlilan there is the value of hard work, namely in welcoming the tablilan tradition in the community, the family of the deceased is assisted by neighbors, volunteers or people who are used to helping if there are events usually try to provide food for people who attend the tradition. They work hard to prepare the dishes that will be served to the audience. Dishes are sometimes made on purpose. The presentation of the dish here is never determined, but usually the presentation of the dish is accompanied by blessings.

In the distribution of blessings, in terms of giving thanks to the leader of tablil. The gift was in addition to extra blessings and an envelope containing money. Indeed, this is not considered excessive because it has complied with the request from the host. The brothers of the host also received different blessings. Lastly, guests who come from neighbors and / or congregations also get blessings. All of that as gratitude for praying for the deceased and also as a form of shodaqoh whose reward is given to the deceased. 
JNUS: Journal of Nahdlatul Ulama Studies, Vol. 2, No. 1, Januari 2021: 1-16

Even when the implementation of tablilan is finished, shohibul hajat cleans the place that has been used. Usually assisted by villagers. All that happens voluntarily and feelings of mutual need for one another. This shows that the values of hard work character education are found in the tablilan tradition.

\section{Communicative}

Friendly/communicative are attitudes and actions that show a sense of pleasure in talking, hanging out, and collaborating with others. Friendly attitude is different from communicative but in a friendly attitude there is a communication process. Friendly/communication attitude shows a person's ability to convey his ideas or a thought to others in socializing. So this attitude is an important asset in social life.

In tablilan there is friendly/communicative, that is, between guests and the family of the deceased can communicate with each other such as saying sorry, can entertain the family so that the deceased can sincerely let go of the deceased and lighten the burden of the disaster and invite him to do dzikr to remember Allah.

Through tablilan, community development will be formed through communication channels, togetherness between young and old generations. With the construction of this communication model, it will generate a sense of respect and appreciation for the previous generation. This is a form of ukhwah Islamiyah which is manifested through the Tahlilan Tradition (Andi Warisno, 2017:76).

Then the tablilan tradition in the community, generally interacting with each other, at least shaking hands or spreading a smile to residents when meeting before starting the tahlilan activities. After the activity is completed, Shohibul Hajat provides food/beverage dishes to the residents. While enjoying the dish, the residents interact and exchange ideas with each other. This aims to be able to grow or play an important role in maintaining friendship between villagers.

\section{Social care}

Social care is an attitude and action that always wants to provide assistance to other people and communities in need. Social care is awareness as a social being that cannot live alone. Humans need other people to meet 
their needs so that there is an interdependence between one individual and another. As social beings, of course, humans will feel the suffering and difficulties of others so that there is a desire to provide help and assistance to people who are in trouble.

Humans have a sense of empathy, a sense of feeling what other people feel and with that their hearts are moved to help others. Therefore, in essence, humans are creatures who like to help and the basis of helping out also seems to be a feeling of mutual need, which is in the souls of the community.

In tablilan there is social care, namely sympathy and condolences to the family of the deceased and praying and all the sins that have been committed while living in the world, are forgiven by Allah SWT. In addition, the grave was opened and the grave was given by Allah SWT and the reward of the Al-Qur'an recitation and dhikr from relatives and neighbors was given to the deceased.

In terms of food, for seven days in a row the mothers (neighbors and close relatives of the deceased) helped in the preparation of dishes (meals, drinks) for the invitation, because in the tablilan tradition not a few were present. Even when the implementation of tahlilan is finished, they together clean the places that have been used. In social care, there is a relationship of interdependence as a result of the exchange process which gives reciprocity in return for services provided by others to themselves. Social care in the Tahlilan Tradition occurs spontaneously and willingly with the aim of helping those who have a desire and they do not receive rewards in the form of wages.

In addition, there is concern among residents, meaning that when we follow the Tahlilan Tradition there is social concern, namely the intention to attend and give news to neighbors and many others, and what we often encounter is food provided by the host, this can be a charity and additional enthusiasm for residents to perform tahlilan tardisi.

This proves that the tablilan tradition has an important role in social society. Moreover, the tablilan tradition in the village is carried out in anjangsana manner. So like it or not, you have to attend the homes of residents who have a passion for tahlilan activities. In addition, the tahlilan tradition is carried out in every association such as a collection of RT, RW, independence thanksgiving events and so on. Practical pseudo- 
JNUS: Journal of Nahdlatul Ulama Studies, Vol. 2, No. 1, Januari 2021: 1-16

religious associations also use the tablilan tradition. With that, if you don't follow the tablilan tradition, of course, the social community will be lacking, due to the lack of participating in the activities of social gatherings or religious associations.

\section{Discipline}

Discipline is an action that shows orderly behavior and obeys various rules and regulations. In daily life we cannot be separated from activities or activities, sometimes we do these activities on time but sometimes we don't. Activities that we carry out in a timely manner and are carried out continuously, will cause a habit. The habit of carrying out activities regularly and on time is what is usually called discipline in everyday life. Discipline is needed anywhere, because with discipline an orderly and orderly life will be created.

In tablilan there is a value of discipline, especially for students in Islamic boarding schools. All students are required to take part in the tablilan activities which have become a requirement for Islamic boarding schools. Tablilan is led by students who have been scheduled from the Head of the Islamic Boarding School. This tradition is carried out in turns every Friday night after maghrib. Beginning with reading surah Yasin and ending with a prayer. If students do not participate in or violate these activities, they will be subject to sanctions/takzirs that have been agreed upon by the students.

This can bond the emotional of students and grow a sense of kinship. And it can also be a provision for the students, so that when in the community they can lead tablil in their village. tablilan tradition is a characteristic of Salaf Islamic boarding schools that preserve the traditions and culture of the archipelago.

\section{Internalization of Character Values in Tahlilan Tradition}

According to Thomas Lickona, the process of internalizing character values contains internalization stages, namely moral knowing, moral feeling and moral action (Thomas Lickona, 2015:84). The interrelationship between the three components in character building theory can also apply to the cultivation of character education values in the tahlilan tradition. 
Because the most important thing in this process is how a value can be practiced and attached to everyday life.

For the Indonesian people the tablilan tradition is a tradition that makes them aware of the values of character education taught through the community, for example related to the value of religious character education. So it arises for them to believe that a tradition like this has character values that must be maintained.

The tablilan tradition is seen as a way to get closer to Allah (Muhyiddin Abdusshomad, 2009:12). This shows that tablilan has become a tradition which has become a valuable lifestyle for society. A hereditary religious tradition accepted by the community is a natural cultural process that occurs in society to maintain the values inherited based on a strong cultural background both from the family environment and from the community environment (Eka Octalia Indah Librianti dan Zaenal Mukarom, 2019:14).

In cultivating character values, it is strongly influenced by actors in the community environment where they interact and socialize. The first reference group that is acted out is that played by the parents and the next is what is done by the surrounding community. This can be seen through the routine tablilan tradition, in villages that have regular discussion activities that are followed by the village community and students once a week.

This activity aims to make people not only know about the tablilan tradition, but also to believe that it is an Islamic tradition brought by Wali Songo by promoting cultural or cultural methods. Where there are many values that can be practiced, especially the values of character education.

In addition, it can minimize the emergence of conflicts over the acceptance of tahlilan by various groups who reject it. The occurrence of fractions in the acceptance of the tahlilan tradition is actually detrimental to Muslims themselves and contradicts the essence contained in the tablilan tradition, namely to uphold Islamic brotherhood.

Furthermore, in the process of internalizing values, namely through moral actions which are the embodiment of moral knowing and moral feeling. To find out what drives someone to do good deeds can be seen from the ability to change moral judgments and feelings into an effective 
JNUS: Journal of Nahdlatul Ulama Studies, Vol. 2, No. 1, Januari 2021: 1-16

moral action, the desire to protect emotions and thoughts and get used to (Thomas Lickona, 2015:84).

The habituation of character education values is the final stage of a process of internalizing a value. This strategy is effectively applied to the community from an early age by providing exercises and getting used to doing it every day. If character habituation is carried out early, it will be reflected in everyday life (Muhammad Munif, 2017:7).

In instilling the values of character education, it does not stop at moral knowing, but also moral feeling and moral action. So religious attitudes, hard work, communication, social care, discipline that exist in the values of character education which are then owned by the community are not only at the level of knowing, but they really feel for themselves the importance of having these characteristics.

This can be proven by the habit of carrying out routine tablilan, ziarah, ribaan and manaqiban. With this, how the values contained in the tablilan tradition can establish a verbal relationship between beings and the Creator or more often known as habluminallah.

In addition, in other aspects, it can be shown by how the values of character education contained in the tahlilan tradition are formed through horizontal relationships, namely the relationship between fellow beings or in another sense hablum minannas. The tablilan tradition can be a medium for social cohesiveness or closeness between communities, strengthening solidarity and friendship (ukhwah Islamiyah)

The habituation of character education values is an activity that is carried out concessional, so that the purpose of the habituation is to strengthen these values so that they become permanent (Indah Khomsiyah dan Chusnul Chotimah, 2015:125). Through the tablilan tradition, it shows that the values of character education can be internalized through activities that are carried out consistently and the community is able to manifest it in the form of behavior in everyday life.

\section{CONCLUSION}

From the above explanation, we can conclude that tablilan is a tradition that makes them aware of the values of character education taught through the community, for example related to the value of religious character education. So it arises for them to believe that a tradition like 
this has character values that must be maintained. The tablilan tradition is one of the local wisdoms possessed by the Indonesian nation, so there are several values of character education in it, including religious values namely one's thoughts, words and actions which are based on divine values.

\section{REFERENCES}

Tim Pakar Yayasan Jati Diri Bangsa, Pendidikan Karakter di Sekolah : Dari Gagasan ke Tindakan Jakarta: Kompas Gramedia, 2011

Abdusshomad, Muhyiddin. Tablilan dalam Perspektif Al-Qur'an dan Assunnah. Jember: PP. Nurul Islam, 2009.

Asmani, Jamal Ma'mur. Buku panduan internalisasi pendidikan karakter di sekolah. Banguntapan, Jogjakarta: DIVA Press, 2011.

Character matters: persoalan karakter: bagaimana membantu anak mengembangkan penilaian yang baik, integritas, dan kebajikan penting lainnya / Thomas Lickona. Jakarta: Bumi Aksara, 2015. http://opac.library.um.ac.id/oaipmh/../index.php?s_data=bp_buk u\&s_field $=0 \& \bmod =$ b\&cat $=3 \& i d=55481$.

Kekerasan Remaja Indonesia Mencapai 50 Persen - Fakultas Kedokteran, Kesehatan Masyarakat dan Keperawatan." Accessed on 5 August 2020. https://fk.ugm.ac.id/kekerasan-remaja-indonesia-mencapai50-persen/.

Kementrian, Pendidikan Nasional. Panduan Pelaksanaan Pendidikan Karakter. Jakarta: Badan Penelitian dan Pengembangan Pusat Kurikulum dan Pembukuan, 2011.

Khomsiyah, Indah, dan Chusnul Chotimah. "AKTUALISASI SISTEM NILAI DALAM MEMBANGUN BUDAYA ORGANISASI LEMBAGA PENDIDIKAN Studi Multikasus Di MAN 2 Tulungagung Dan SMAN 1 Boyolangu Tulungagung." Dinamika Penelitian: Media Komunikasi Penelitian Sosial Keagamaan 15, no. 1 (2015):

117-132-132. https://doi.org/10.21274/dinamika.2015.15.1.117-132. 
JNUS: Journal of Nahdlatul Ulama Studies, Vol. 2, No. 1, Januari 2021: 1-16

Librianti, Eka Octalia Indah, dan Zaenal Mukarom. "Budaya Tahlilan Sebagai Media Dakwah." Prophetica: Scientific and Research Journal of Islamic Communication and Broadcasting 5, no. 1 (30 June 2019): 1-20.

Mahbubi, M. Pendidikan karakter: implementasi aswaja sebagai nilai pendidikan karakter, 2012.

Metodologi penelitian kualitatif / Lexy J. Moleong. Bandung: Remaja Rosdakarya, 2010.

http://opac.library.um.ac.id/oaipmh/../index.php?s_data=bp_buk u\&s_field $=0 \& \bmod =$ b\&cat $=3 \& i d=38045$.

Munif, Muhammad. "STRATEGI INTERNALISASI NILAI-NILAI PAI DALAM MEMBENTUK KARAKTER SISWA.” EDURELIGLA: Jurnal Pendidikan Agama Islam 1, no. 1 (2017): 1-12. https://doi.org/10.33650/edureligia.v1i2.49.

Mustari, Mohamad. "Refleksi Untuk Pendidikan Karakter," t.t., 13.

Pendidikan karakter di sekolah: dari gagasan ke tindakan (Book, 2011) [WorldCat.org]." Accessed on 5 August 2020. https://www.worldcat.org/title/pendidikan-karakter-di-sekolahdari-gagasan-ke-tindakan/oclc/820901926\&referer=brief_results.

Priyatna, Muhammad. "PENDIDIKAN KARAKTER BERBASIS KEARIFAN LOKAL." Edukasi Islami: Jurnal Pendidikan Islam 5, no. 10 (25 October 2017). https://doi.org/10.30868/ei.v5i10.6.

Warisno, Andi. "Tradisi Tahlilan Upaya Menyambung Silaturahmi." Riayah: Jurnal Sosial Dan Keagamaan 2, no. 02 (21 December 2017): 69-97. https://doi.org/10.32332/riayah.v2i02.981. 